\title{
Additional Host Plants of Four Species of Billbug Found on New Jersey Turfgrasses
}

\author{
Jennifer M. Johnson-Cicalese ${ }^{1}$ and C.R. Funk \\ Crop Science Department, New Jersey Agricultural Experiment Station, Rutgers University, New \\ Brunswick, NJ 08903
}

\begin{abstract}
Additional index words. Sphenophorus parvulus, S. venatus, S. minimus, S. inaequalis, Poa, Festuca, Lolium, Cynodon
Abstract. Studies were conducted on the host plants of four billbug species (Coleoptera:Curculionidae: Sphenophorus parvulus Gyllenhal, $S$. venatus Chitt., $S$. inaequalis Say, and $S$. minimus Hart) found on New Jersey turfgrasses. A collection of $\mathbf{4 8 0 3}$ adults from pure stands of various turfgrasses revealed all four billbugs on Kentucky bluegrass (Poa pratensis L.), tall fescue (Festuca arundinacea Schreb.), and perennial ryegrass (Lolium perenne L.), and $S$. parvulus, $S$. venatus, and $S$. minimus on Chewings fescue ( $F$. rubra $\mathbf{L}$. ssp. commutata Gaud.). Since the presence of larvae, pupae, or teneral adults more accurately indicates the host status of a grass species, immature billbugs were collected from plugs of the various grass species and reared to adults for identification. All four species were reared from immature billbugs found in Kentucky bluegrass turf; immatures of $S$. venatus, $S$. inaequalis, and $S$. minimus were found in tall fescue; $S$. venatus and $S$. minimus in perennial ryegrass; and $S$. inaequalis in strong creeping red fescue (F. rubra L. ssp. rubra). A laboratory experiment was also conducted in which billbug adults were confined in petri dishes with either Kentucky bluegrass, perennial ryegrass, tall fescue, or bermudagrass (Cynodon dactylon Pers.). Only minor differences were found between the four grasses in billbug survival, number of eggs laid, and amount of feeding. In general, bermudagrass was the least favored host and the other grasses were equally adequate hosts. The results of this study indicate a need for updating host-plant lists of these four billbug species.
\end{abstract}

Billbugs (Sphenophorus spp.) are ranked among the most serious turfgrass insect pests (Tashiro, 1987). In the northeastern United States, the bluegrass billbug ( $S$. parvulus) has been considered the only billbug species that damages turfgrass. However, recent pitfall trap collections made on New Jersey turfs found four species of billbug in almost equal abundance: bluegrass billbug, hunting billbug (S. venatus), uneven billbug ( $S$. inaequalis), and little billbug (S. minimus) (Johnson-Cicalese et al., 1990). This finding necessitated a re-examination of billbugs in New Jersey, including work on their biology (Johnson-Cicalese et al., 1990), the effects of Acremonium endophytes on the four species (Johnson-Cicalese and White, 1990), and, as described in this paper, an evaluation of the host-plant ranges of the four billbugs.

Information on the host plants of billbugs is very limited. The only major host-plant list was compiled by Satterthwait (1931). Fifteen grass hosts were listed for S. parvulus, with Kentucky bluegrass (Poa pratensis) as the preeminent host; three grass species for $S$. venatus, including the turf species bermudagrass (Cynodon dactylon); 12 grasses for S. minimus; and only bermudagrass for $S$. inaequalis. Since 1931, several additional host plants have been recorded. $S$. parvulus has been reported on perennial ryegrass (Lolium perenne) (Ahmad et al., 1986), strong creeping red fescue ( $F$. rubra ssp. rubra) and other fine fescues (Dickson et al., 1984), bentgrass (Agrostis spp.) (Kamm, 1969), and 15 additional species and interspecific hybrids of range grasses in Montana (Asay et al., 1983). In another study with $S$. parvulus, Kindler et al. (1983) found that Kentucky bluegrass was the only grass of 11 turfgrass species that had more than one

Received for publication 12 June 1989. New Jersey Agricultural Experiment Station Publication no. D-15264-5-89 supported by State and U.S. Hatch Act Funds. We thank H. Tashiro, H.T. Streu, D.N. Reimer, D. Shetlar, and R.N. Ratcliffe for their advice and assistance with this project and J. Breen, S. Sun, M. Kemp, and R.F. Bara for technical assistance. The cost of publishing this paper was defrayed in part by the payment of page charges. Under postal regulations, this paper therefore must be hereby marked advertisement solely to indicate this fact.

'Current address: Dept. of Plant Sciences, Univ. of Rhode Island, Kingston, RI 02881. larvae feeding on it per $9.3 \mathrm{dm}^{2}$ of sod. Recent hosts listed for S. venatus are zoysiagrass (Zoysia spp.) (Kelsheimer, 1956); orchardgrass (Dactylus glomeratus L.) (Kamm, 1969); St. Augustinegrass (Stenotaphrum secundatum Kuntze); centipedegrass (Eremochloa ophiuroides Hack); and 'Pensacola' bahiagrass (Paspalum notatum Flugge) (Oliver, 1984). Only one additional host has been reported for both $S$. minimus (bermudagrass) (Van Dyke, 1938) and S. inaequalis (crabgrass, Digitaria spp.) (D. Shetlar, personal communication). Unfortunately, several of these studies looked at billbug larvae and very few, if any, adults. If additional billbug species had been present, they may have gone unrecognized because there is no method for identifying the larvae to species.

\section{Materials and Methods}

Three methods were used to evaluate the host-plant range of the four billbug species: 1) the presence and abundance of adults in several grass species were determined; 2) immature stages were collected, reared to adults, and identified; and 3) a laboratory experiment was conducted to measure billbug fitness on several host grasses.

In 1986, eight linear pitfall traps were placed in solid stands of various turfgrass species, each stand covering $\approx 0.25$ ha; two at the Turfgrass Research Center in North Brunswick, N.J., and six at the Soils and Crops Research Center in Adelphia, N.J. The traps in North Brunswick were placed on 2 May in perennial ryegrass and tall fescue (Festuca arundinacea) cultivar evaluation trials. At Adelphia, four traps were placed 2 May in two tall fescue trials, a Kentucky bluegrass trial, and a Chewings fescue ( $F$. rubra ssp. commutata) trial, and two traps were placed on 1 Sept. in additional tall fescue and Kentucky bluegrass trials (see Table 1). All traps were separated from each other by at least $60 \mathrm{~m}$. Each trap consisted of a 2-m-long, 6.4-cm-diameter PVC pipe, with a $1-\mathrm{cm}$ slit cut in it lengthwise; the pipe was buried flush with the ground, with a collecting can at one end (similar to Lawrence, 1982). Eight new traps were placed on 1 Apr. 1987, two in North Brunswick and six at Adelphia (see Table 1). The two traps in North Brunswick were placed in solid stands of Kentucky bluegrass and tall fescue. The six traps 
Table 1. Distribution of billbug species on several species of grass collected from pitfall traps at Adelphia (A) and North Brunswick (NB), N.J., during 1986 and 1987.

\begin{tabular}{|c|c|c|c|c|c|c|c|c|}
\hline \multirow[b]{2}{*}{ Grass species } & \multirow{2}{*}{$\begin{array}{c}\text { Trap } \\
\text { location }\end{array}$} & \multirow{2}{*}{$\begin{array}{c}\text { Collection } \\
\text { period }\end{array}$} & \multicolumn{4}{|c|}{ No. of adults ${ }^{2}$} & \multirow{2}{*}{$\begin{array}{c}\text { Unidentifiedy } \\
\text { May-June } 1986\end{array}$} & \multirow[b]{2}{*}{ Total } \\
\hline & & & S.v. & S.i. & S.m. & S.p. & & \\
\hline Kentucky bluegrass & $\begin{array}{l}\mathrm{A} \\
\mathrm{A} \\
\mathrm{NB} \\
\mathrm{A} \\
\mathrm{A} \\
\mathrm{A}\end{array}$ & $\begin{array}{l}\text { May-Nov. } 1986 \\
\text { Oct.-Nov. } 1986 \\
\text { Apr.-Nov. } 1987 \\
\text { Apr.-Nov. } 1987 \\
\text { Apr.-Nov. } 1987 \\
\text { Apr.-Nov. } 1987\end{array}$ & $\begin{array}{r}81 \\
7 \\
57 \\
170 \\
156 \\
120 \\
591\end{array}$ & $\begin{array}{r}400 \\
0 \\
9 \\
766 \\
2 \\
57 \\
1234\end{array}$ & $\begin{array}{r}33 \\
3 \\
14 \\
381 \\
13 \\
280 \\
724\end{array}$ & $\begin{array}{r}20 \\
10 \\
14 \\
406 \\
19 \\
258 \\
727\end{array}$ & 255 & $\begin{array}{r}789 \\
20 \\
94 \\
1723 \\
190 \\
715 \\
3531\end{array}$ \\
\hline $\begin{array}{c}\text { Tall fescue } \\
\qquad \\
\text { Total }\end{array}$ & $\begin{array}{l}\mathrm{NB} \\
\mathrm{A} \\
\mathrm{A} \\
\mathrm{A} \\
\mathrm{NB} \\
\mathrm{A}\end{array}$ & $\begin{array}{l}\text { May-Nov. } 1986 \\
\text { May-Nov. } 1986 \\
\text { May-Nov. } 1986 \\
\text { Oct.-Nov. } 1986 \\
\text { Apr.-Nov. } 1987 \\
\text { Apr.-Nov. } 1987\end{array}$ & $\begin{array}{r}37 \\
15 \\
9 \\
5 \\
122 \\
154 \\
342\end{array}$ & $\begin{array}{r}1 \\
0 \\
0 \\
75 \\
2 \\
113 \\
191\end{array}$ & $\begin{array}{r}9 \\
14 \\
5 \\
3 \\
34 \\
65 \\
130\end{array}$ & $\begin{array}{r}2 \\
5 \\
0 \\
5 \\
30 \\
91 \\
133\end{array}$ & $\begin{array}{r}305 \\
157 \\
39\end{array}$ & $\begin{array}{r}354 \\
191 \\
53 \\
88 \\
188 \\
423 \\
1297\end{array}$ \\
\hline $\begin{array}{l}\text { Perennial ryegrass } \\
\text { Total }\end{array}$ & $\begin{array}{l}\mathrm{NB} \\
\mathrm{A}\end{array}$ & $\begin{array}{l}\text { May-Nov. } 1986 \\
\text { Apr.-Nov. } 1987\end{array}$ & $\begin{array}{r}56 \\
70 \\
126\end{array}$ & $\begin{array}{l}0 \\
2 \\
2\end{array}$ & $\begin{array}{r}7 \\
80 \\
87\end{array}$ & $\begin{array}{r}0 \\
48 \\
48\end{array}$ & $\begin{array}{l}282 \\
282\end{array}$ & $\begin{array}{l}345 \\
200 \\
545\end{array}$ \\
\hline $\begin{array}{l}\text { Chewings fescue } \\
\text { Bermudagrass/ } \\
\text { tall fescue }\end{array}$ & $\mathrm{A}$ & $\begin{array}{l}\text { May-Nov. } 1986 \\
\text { Apr.-Nov. } 1987\end{array}$ & 175 & 62 & 31 & 144 & 207 & 251 \\
\hline $\begin{array}{l}\text { Total } \\
\text { Percent of each } \\
\quad \text { species }\end{array}$ & & & 1245 & 1486 & 1015 & $\begin{array}{r}1054 \\
22\end{array}$ & 1245 & 6048 \\
\hline
\end{tabular}

${ }^{\mathrm{z}}$ S.v. $=$ S. venatus, S.i. $=$ S. inaequalis, S.m. $=$ S. minimus, S.p. $=$ S. parvulus.

yIn 1986, billbugs were not identified from 2 May through 24 June. Thereafter ( 25 June-10 Nov.), all billbugs were identified to species.

at Adelphia were placed in three Kentucky bluegrass trials, one perennial ryegrass, one tall fescue, and an old tall fescue test heavily contaminated with bermudagrass. Twice a week, until mid-November, the number and species of billbugs in each trap were recorded (Table 1). Species identification did not begin in 1986 until 24 June.

During July 1986 and 1987, larvae, pupae, and teneral adults were collected from plugs of Kentucky bluegrass, tall fescue, perennial ryegrass, and strong creeping red fescue. In 1986, all immature billbugs found were placed in plastic vials with moist soil and placed on a laboratory bench for rearing to the adult stage and subsequent identification. In 1987, immatures were placed in 30-ml plastic creamer cups containing Bioserv's sod webworm diet (product no. F9754; Frenchtown, N.J.). The cups were covered and kept in a laboratory with a L14:D10 photoperiod and temperatures between 21 and $27 \mathrm{C}$ until the billbugs emerged as adults.

A laboratory experiment, designed to measure the effect of host plant on adult survival, oviposition, and feeding (similar to Wright et al., 1982), was conducted from 17 Apr. to 21 Sept. 1987. Four male and four female billbugs were placed in a 10$\mathrm{cm}$ petri dish containing moist filter paper and tillers of either Kentucky bluegrass, endophyte-free perennial ryegrass, endophyte-free tall fescue, or bermudagrass. Grass tillers were removed as needed from plants that had been dug from nurseries in April, potted, and maintained outside. Whenever enough billbugs of one species were collected from pitfall traps, a replication of this experiment was initiated. Consequently, the number of replications was different for each species of billbug (ranging from three to six), and the starting dates for each replication ranged from 17 Apr. to 6 Aug. The dishes were held in the laboratory at a photoperiod of L14:D10 and between 21 and
27C. Twice a week, mortality, number of eggs laid, and feeding score (using a scale of 1 to 5 , where $5=$ no feeding and $1=$ extensive feeding and severe leaf damage) were recorded and fresh filter paper and grass tillers were provided.

\section{Results and Discussion}

From our collection of 4803 identified billbug adults, it is apparent that four billbug species are present in New Jersey turfs in nearly equal abundance (Table 1). On Kentucky bluegrass and tall fescue, many adults of all four billbug species were found, indicating that they are all able to feed and ovipost on these two grass species. However, billbug damage was significantly more severe on the Kentucky bluegrass turf. Considerably more of the adults on tall fescue (43\% of the total) were $S$. venatus, suggesting that a larger billbug, as is $S$. venatus, may prefer a coarser grass. The two traps in perennial ryegrass yielded four billbug species, but $S$. inaequalis adults were only $1 \%$ of the total collected. Very few billbugs were collected from the one trap placed in a Chewings fescue turf and no $S$. inaequalis and very few $S$. parvulus were found. It is possible that larger collections from perennial ryegrass and Chewings fescue would reveal a more equal abundance of the four billbug species. Because the only recorded host plant for $S$. inaequalis is bermudagrass (Satterthwait, 1931), we expected to find many of this species in the tall fescue/bermudagrass trap. Instead, this trap contained few $S$. inaequalis; the traps with the highest percentage of $S$. inaequalis were those in Kentucky bluegrass turfs.

Because adult billbugs can wander, the presence of a particular species of billbug in a pitfall trap is not an absolute indication that that species can complete its development on that grass. In addition, Wright et al. (1982) found that southern corn 
billbug ( $S$. callosus Olivier) adults fed on a wider variety of plant species than those on which larvae were able to complete development. Therefore, the presence of larvae, pupae, or teneral adults more accurately indicates the host status of a grass species. Table 2 shows the number of immature billbugs collected from plugs in pure stands of different grass species and the species of immatures that developed into adults. Since many more plugs of Kentucky bluegrass than of other grasses were examined, the numbers in Table 2 are not an indication of billbug density. All four species were reared from immature billbugs found in Kentucky bluegrass turf, S. venatus, S. inaequalis, and $S$. minimus emerged from immatures found in tall fescue; $S$. venatus and $S$. minimus from immatures in perennial ryegrass; and $S$. inaequalis from immatures in strong creeping red fescue turf. Larger collections of immatures from fescue and ryegrass turfs might reveal all four species on these grasses. In addition, developing better rearing methods and sampling for immatures over an entire growing season would probably improve this technique for identifying billbug host plants. It is interesting to note that the one billbug adult that was not found in pitfall trap collections on Chewings fescue turf, $S$. inaequalis, was found as an immature billbug on a closely related subspecies-strong creeping red fescue.

Results from the laboratory experiment, including the number of days until $90 \%$ mortality, amount of feeding, and number of eggs laid for each insect on each grass species, are shown in Table 3. The average survival of the four billbug species was significantly better on perennial ryegrass and tall fescue than on Kentucky bluegrass or bermudagrass. No significant differences were found in the survival of $S$. minimus and $S$. parvulus on each grass, $S$. inaequalis lived significantly longer on perennial ryegrass, and $S$. venatus survived better on perennial ryegrass than bermudagrass. In all cases, survival was shortest on bermudagrass.

The only significant differences found between host grasses in amount of feeding were adults of $S$. venatus, $S$. parvulus, and $S$. inaequalis all fed less on bermudagrass (data for $S$. minimus on bermudagrass not obtained due to lack of specimens). Very small differences were seen in number of eggs laid as well, with the only significant difference being in $S$. parvulusmore eggs were laid on Kentucky bluegrass than bermudagrass. The average of the four insect species shows significantly more eggs on tall fescue than on bermudagrass. However, there are two possible limitations to egg count data. First, the petri dish environment was very different from a natural stand of turf; the female laid eggs on the filter paper instead of depositing them inside the grass tiller. Second, many eggs were laid within the first few days of confinement on a particular diet, indicating that the diet provided in the petri dish may have had little influence on oviposition. In a separate study (Johnson-Cicalese and White, 1990), however, a second- or third-instar billbug larva was found feeding on a potted tall fescue-plant that adults had been confined on, providing further evidence that billbugs will oviposit on tall fescue. The results of this experiment, in general, indicate that bermudagrass is the least favored host and that Kentucky bluegrass, endophyte-free perennial ryegrass, and endophyte-free tall fescue are equally adequate hosts.

A better understanding of billbug host plant preferences is important in developing alternative control strategies for these pests. These strategies might involve using grass blends and/or mixtures that include less-preferred grass species, endophyteinfected grasses, and/or cultivars with genetic resistance to billbugs. Tall fescue has historically been thought to suffer little insect damage because of its tougher root and leaf tissue (Murray and Powell, 1979). Endophyte-infected perennial ryegrass has shown dramatically less billbug damage than endophytefree ryegrass in field studies (Ahmad et al., 1986). In the laboratory, endophyte-infected tall fescue and perennial ryegrass were shown to adversely affect survival of adults of the four billbug species found in New Jersey (Johnson-Cicalese and White,

Table 2. Number and species of immature billbugs ${ }^{\mathbf{z}}$ collected from plugs of four species of turfgrass.

\begin{tabular}{|c|c|c|c|c|c|c|}
\hline \multirow[b]{2}{*}{$\begin{array}{l}\text { Grass } \\
\text { species }\end{array}$} & \multicolumn{3}{|c|}{1986} & \multicolumn{3}{|c|}{1987} \\
\hline & $\begin{array}{l}\text { No. and } \\
\text { species of } \\
\text { teneral } \\
\text { adults } \\
\text { collected }\end{array}$ & $\begin{array}{l}\text { No. of } \\
\text { larvae } \\
\text { and pupae } \\
\text { collected } \\
\text { and placed } \\
\text { in vials } \\
\end{array}$ & $\begin{array}{l}\text { No. and } \\
\text { species } \\
\text { of larvae } \\
\text { and pupae } \\
\text { that emerged } \\
\text { as adults } \\
\end{array}$ & $\begin{array}{l}\text { No. and } \\
\text { species of } \\
\text { teneral } \\
\text { adults } \\
\text { collected } \\
\end{array}$ & $\begin{array}{l}\text { No. of } \\
\text { larvae } \\
\text { and pupae } \\
\text { collected } \\
\text { and placed } \\
\text { on diet } \\
\end{array}$ & $\begin{array}{l}\text { No. and } \\
\text { species } \\
\text { of larvae } \\
\text { and pupae } \\
\text { that emerged } \\
\text { as adults } \\
\end{array}$ \\
\hline Kentucky & & & & & & \\
\hline bluegrass & 1. S.i. & $114^{y}$ & $\begin{array}{l}5 \text { S.v. } \\
2 \text { S.i. } \\
3 \text { S.m. }\end{array}$ & $\begin{array}{l}3 \text { S.v. } \\
2 \text { S.i. } \\
4 \text { S.m. } \\
6 \text { S.p. }\end{array}$ & 200 & $\begin{array}{l}10 \text { S.v. } \\
4 \text { S.i. } \\
22 \text { S.m. } \\
13 \text { S.p. }\end{array}$ \\
\hline Tall fescue & & 13 & $\begin{array}{l}1 \text { S.v. } \\
1 \text { S.i. } \\
1 \text { S.m. }\end{array}$ & & 1 & 0 \\
\hline $\begin{array}{l}\text { Perennial } \\
\text { ryegrass }\end{array}$ & & 3 & 0 & & 9 & $\begin{array}{l}1 \text { S.v. } \\
1 \text { S.m. }\end{array}$ \\
\hline $\begin{array}{l}\text { Strong creeping } \\
\text { red fescue }\end{array}$ & & 20 & 2 S.i. & & & \\
\hline
\end{tabular}

${ }^{z}$ S.v. $=S$. venatus, S.i. $=$ S. inaequalis, S.m. $=S$. minimus; S.p. $=$ S. parvulus .

yNumbers of billbugs are not an indication of density, many more plugs of Kentucky bluegrass were examined than of other grasses. 
Table 3. Billbug mortality, feeding, and egg laying on four grasses in a laboratory trial. ${ }^{2}$

\begin{tabular}{|c|c|c|c|c|c|}
\hline \multirow[b]{2}{*}{ Grass species } & \multicolumn{4}{|c|}{ Billbug species ${ }^{y}$} & \multirow[b]{2}{*}{ Mean } \\
\hline & S.m. & S.i. , & S.p. & S.v. & \\
\hline \multicolumn{6}{|c|}{ No. days until $90 \%$ mortality } \\
\hline Perennial ryegrass & $53 \mathrm{a}$ & $57 \mathrm{a}$ & $27 \mathrm{a}$ & $34 \mathrm{a}$ & $43 \mathrm{a}$ \\
\hline Tall fescue & $57 \mathrm{a}$ & $36 \mathrm{~b}$ & $41 \mathrm{a}$ & $33 a b$ & $42 \mathrm{a}$ \\
\hline Kentucky bluegrass & $40 \mathrm{a}$ & $32 \mathrm{~b}$ & $21 \mathrm{a}$ & $23 \mathrm{ab}$ & $29 \mathrm{~b}$ \\
\hline Bermudagrass & $-\cdots$ & $27 \mathrm{~b}$ & 20 a & $14 \mathrm{~b}$ & $20 \mathrm{~b}$ \\
\hline \multicolumn{6}{|c|}{ Feeding rating ${ }^{x}$} \\
\hline Kentucky bluegrass & $2.4 \mathrm{a}$ & $2.6 \mathrm{a}$ & $2.3 \mathrm{a}$ & $2.6 \mathrm{a}$ & $2.5 \mathrm{a}$ \\
\hline Tall fescue & $2.8 \mathrm{a}$ & $2.7 \mathrm{ab}$ & $2.7 \mathrm{a}$ & $2.2 \mathrm{a}$ & $2.6 \mathrm{a}$ \\
\hline Perennial ryegrass & $3.0 \mathrm{a}$ & $2.8 \mathrm{ab}$ & $2.9 \mathrm{a}$ & $2.3 \mathrm{a}$ & $2.8 \mathrm{a}$ \\
\hline Bermudagrass & $\cdots$ & $3.2 \mathrm{~b}$ & $4.1 \mathrm{~b}$ & $3.4 \mathrm{~b}$ & $3.6 \mathrm{~b}$ \\
\hline \multicolumn{6}{|c|}{ No. eggs laid per female } \\
\hline Tall fescue & $1.6 \mathrm{a}$ & $0.6 \mathrm{a}$ & $1.2 \mathrm{ab}$ & $2.8 \mathrm{a}$ & $1.6 \mathrm{a}$ \\
\hline Kentucky bluegrass & $1.0 \mathrm{a}$ & $1.0 \mathrm{a}$ & $1.6 \mathrm{a}$ & $1.9 \mathrm{a}$ & $1.4 \mathrm{ab}$ \\
\hline Perennial ryegrass & $1.3 \mathrm{a}$ & $0.5 \mathrm{a}$ & $1.1 \mathrm{ab}$ & $1.3 \mathrm{a}$ & $1.1 \mathrm{ab}$ \\
\hline Bermudagrass & --- & $0.5 \mathrm{a}$ & $0.3 \mathrm{~b}$ & $1.3 \mathrm{a}$ & $0.7 \mathrm{~b}$ \\
\hline
\end{tabular}

'Mean separation within a column (within a criterion) by Duncan's multiple range test, $P=0.05$. Three to seven replications, depending on insect species.

${ }^{y} \mathrm{~S} . \mathrm{v}=S$. venatus, $\mathrm{S} . \mathrm{i} .=S$. inaequalis, $\mathrm{S} . \mathrm{m} .=S$. minimus, S.p. $=S$. parvulus.

${ }^{x}$ Rating scale of 1 to $5 ; 5=$ no feeding, $1=$ extensive feeding and severe leaf damage.

1990). Perhaps the frequency of endophyte infection in many other grasses (Siegel et al., 1987), and the apparent absence of Acremonium endophytes in Kentucky bluegrass, maybe related to the high incidence of billbug damage in Kentucky bluegrass. Numerous studies with Kentucky bluegrass, however, have identified cultivars with significant genetic resistance to billbugs, and several mechanisms of resistance have been suggested (Ahmad and Funk, 1982; Bruneau et al., 1987; Kindler and Kinbacher, 1975; Lindgren et al., 1981).

In conclusion, $S$. parvulus, $S$. venatus, $S$. minimus, and $S$. inaequalis are present and apparently able to develop on at least four major cool-season turfgrasses; i.e., Kentucky bluegrass, tall fescue, perennial ryegrass, and fine fescues. However, hostplant lists for billbugs are far from complete. In addition, billbugs other than just the bluegrass billbug are causing turfgrass damage in New Jersey and the northeastern United States. In fact, the equal abundance of the four billbug species in the field and results from the laboratory experiment, indicate that each of the four species may cause substantial turf injury.

\section{Literature Cited}

Ahmad, S. and C.R. Funk. 1982. Susceptibility of Kentucky bluegrass cultivars and selections to infestations of and injury by the bluegrass billbug (Coleoptera:Curculionidae). N.Y. Entomol. Soc. 29:31-34.
Ahmad, S., J.M. Johnson-Cicalese, W.K. Dickson, and C.R. Funk. 1986. Endophyte-enhanced resistance in perennial ryegrass to the bluegrass billbug, Sphenophorus parvulus. Entomol. Expt. Appl. 41:3-10.

Asay, K.H., J.D. Hansen, B.A. Haws, and P.O. Currie. 1983. Genetic differences in resistance of range grasses to the bluegrass billbug, Sphenophorus parvulus (Coleoptera:Curculionidae). J. Range Mgt. 36:771-772.

Bruneau, A.H., A.M. Parkhurst, and R.C. Shearman. 1987. Discriminant analysis for Kentucky bluegrass billbug resistance ratings. J. Amer. Soc. Hort. Sci. 112:978-980.

Dickson, W.K., R.F. Bara, and C.R. Funk. 1984. Performance of fine fescue cultivars and selections in turf evaluation trials at the Soils and Crops Research Center, Adelphia, New Jersey. Rutgers Turfgrass Proc. 15:113-123.

Johnson-Cicalese, J.M. and R.H. White. 1990. Effect of Acremonium endophyte on four species of billbug found on New Jersey turf. J. Amer. Soc. Hort. Sci. 115(4):602-604.

Johnson-Cicalese, J.M., G.W. Wolfe, and C.R. Funk. 1990. Biology, distribution and taxonomy of billbug turf pests. Environ. Entomol. (In press.)

Kamm, J.A. 1969. Biology of the billbug Sphenophorus venatus confluens, a new pest of orchardgrass. J. Econ. Entomol. 62:808-812.

Kelsheimer, E.G. 1956. The hunting billbug, a serious pest of zoysia. Proc. Florida State Hort. Soc. 69:415-418.

Kindler, S.D. and E.J. Kinbacher. 1975. Differential reaction of Kentucky bluegrass cultivars to the bluegrass billbug, Sphenophorus parvulus Gyllenhal. Crop Sci. 15:873-874.

Kindler, S.D., S.M. Spomer, and E.J. Kinbacher. 1983. Further host range studies on the bluegrass billbug, Sphenophorus parvulus Gyllenhal (Coleoptera:Curculionidae). Environ. Entomol. 12:528-530.

Lawrence, K.O. 1982. A linear pitfall trap for mole crickets and other soil arthropods. Sci. Notes, Florida Entomol. 65:376-377.

Lindgren, D.T., R.C. Shearmen, A.H. Bruneau, and P.M. Schaaf. 1981. Kentucky bluegrass cultivar response to bluegrass billbug, Sphenophorus parvulus Gyllenhal. HortScience 16:339.

Murray, J.J. and J.B. Powell. 1979; Tall fescue, p. 293-306. In: R.C. Buckner and L.P. Bush (eds.). Turf. Agronomy Series 20. Amer. Soc. Agron., Madison, Wis.

Oliver, A.D. 1984. The hunting billbug-One among the complex of turfgrass insect and pathogen problems. Amer. Lawn Appl. Mar./ Apr. p. 24-27.

Satterthwait, A.F. 1931. Key to known pupae of the genus Calendra, with host-plant and distribution notes. Ann. Entomol. Soc. Amer. 24:143-172.

Siegel, M.R., G.C.M. Latch, and M.C. Johnson. 1987. Fungal endophyte of grasses. Annu. Rev. Phytopathol. 25:293-315.

Tashiro, H. 1987. Turfgrass insects of the United States and Canada. Cornell University Press, Ithaca, N.Y.

Van Dyke, E.C. 1938. Calendra (Sphenophorus) minimus Hart in California. Pan-Pacific Entomol. 14:187.

Wright, R.J., J.W. van Duyn, and J.R. Bradley, Jr. 1982. Host range of southern corn billbug (Coleoptera:Curculionidae) adults and larvae. Environ. Entomol. 11:954-957. 